\title{
WORKING THROUGH HUNTER S. THOMPSON'S STRANGE AND TERRIBLE SAGA
}

\author{
JENNIFER HAGEN FORSBERG
}

\begin{abstract}
The subjective and participatory method of New Journalism provides practitioner Hunter S. Thompson access to the kinds of creative, cultural entrepreneurship seen in postwar American narratives. In his reported and written "work," Thompson not only self-consciously performs class personas, but markets those identities as a model of enterprise through creative economy. Thompson's critical perspective and status position approximates what sociologists call a "cultural omnivore," someone who consumes all forms of culture, but who reproduces a position of privilege in doing so. In Hell's Angels (1966), Thompson uses the privilege granted by omnivoracity to transform the limitations of the worker-writer into a commodifiable and safe identity that can access and reign over other social groups. By prioritizing his status as "pro," Thompson manipulates the symbolic and cultural capital of class identity, providing himself an opportunity to feature individual over collective politics. Yet to accomplish this, Thompson relies on representing-and exploiting-the working class. Thompson exemplifies the class performative aspect of a working persona that is able to attain cultural domination through the manipulation of working-class identities in literary markets.
\end{abstract}

\section{KEY WORDS}

Hunter S. Thompson, Cultural omnivore, Celebrity, Working-class identity, Representation

Hunter S. Thompson made a career out of cultivating a notorious outsider position and outlaw writing style. Yet, his professional association with New Journalism was more than a method for expressing countercultural attitudes and political critique in the Sixties and Seventies: Thompson's aesthetic choices and compositional styles questioned the very status of the professional in journalism. These inquiries became a motivating factor in the eccentric and creative ventures Thompson undertook, and still allowed him to claim the status and persona of that generates esteem in literary markets-the working professional. In his Rolling Stone article "Fear and Loathing at the Super Bowl" (1974), Thompson famously claimed, "[w]hen the going gets weird, the weird turn pro" (49). Now a heavily circulated, but decontextualized motto emblazoned on the tee shirts of a new generation singing Thompson's praise for being "weird," Thompson's original sentiment indicates a larger twentieth-century concern with creative labour's ability to market itself. Thompson's work not only questions what it means to go "pro," but explores the performative roles required of a professional journalist and writer. That 1974 article stages the creative process of developing status in the field, the literary market, and in American culture, something Thompson felt correlated to competitive sports and the spectacle 
of the Super Bowl. Whether on the field or in the field, Thompson's interest in turning "pro" becomes a challenge to journalism and an assertion of individuality.

Thompson's working persona was over-determined by a personalised sense of "journalistic responsibility" ("Bowl" 48). His troubled relationship with "professional" journalism indicates he felt a kind of responsibility to himself as a creative labourer, and he often expressed an explicit criticism of the low-earning freelance jobs that defined his status in the literary market. Even from within the progressive and subjective declarations of New Journalism, Thompson challenged the limitations of the profession through his performance of work. These working performances ventured into uncharted creative territory, turning the challenges of genre and discipline into a profession, as Thompson harnessed the "weird" as a method of self-assertion. In promoting himself as a self-made professional, Thompson declared a level of status that marked him both outside and above the traditional techniques or practices of the field. But to perform his working persona, Thompson had to actively subordinate and objectify parts of society to sell readers his own insubordinate and subjective role. This method is clear nearly a decade earlier in Thompson's first major book Hell's Angels: The Strange and Terrible Saga of the Outlaw Motorcycle Gangs (1966), where his nascent working persona enlists a "pro" status through the active manipulation of working-class identity.

\section{HELL'S ANGELS AND THE WORK OF REPRESENTATION}

American journalism has demonstrated long-standing interest in the under- or working class. As critic Thomas Newhouse points out, many of the predecessors of New Journalism can be traced to respected turn-of-the-century progressive texts, which emphasised the practice of "slumming" in the literary modes of realism and naturalism in order to stimulate social change (121). These episodes often featured upper-to-middle class characters that visited or lived in lower-class locations in order to gather knowledge and provide authentic representations of marginal worlds. The productiveness of class-crossing literary performances such as slumming becomes foundational in Tom Wolfe's call for New Journalists to disrupt the literary class hierarchy that ranks journalists as hardly noticeable members of the lower class, only above the "so-called free-lance writers," or "lumpenproles" ("American Novel" 153). Unwilling to be subordinate to novelists, Wolfe calls on New Journalists to "tak[e] on all of these [class] roles at the same time [...] ignoring literary class lines that have been almost a century in the making" ("American Novel" 153). Through slumming and crossing literary class lines, these interpretations of American journalism indicate that class identity can be a creative resource and a method for making content valuable and marketable.

The fluid positionality of writers who engage with slumming and class crossing suggests a privileged position within the culture industry. An examination of these privileged positions benefits from Richard A. Peterson and Roger M. Kern's formulation of the "cultural omnivore," a postmodern figure who does not consume "everything indiscriminately" in culture, but "[r]ather ... signifies an openness to appreciating everything" (904). A cultural omnivore is able to accumulate the kind of cultural capital that Pierre Bourdieu establishes in Distinction (1986): to identify and participate in cultural practices that have value. Thompson's work shows the ability to appreciate and participate in a variety of cultural institutions. However, this access requires him to construct an effective working persona dependent on a multitude of marketable narratives, especially those that elicit tension between middle-class and working-class identities. This paper traces this phenomenon in Hell's Angels, where Thompson's working persona consistently markets itself by transgressing literary and social class lines.

Hell's Angels is the text that secures Thompson's writing career and his working persona as cultural critic. First published in 1965 as "The Motorcycle Gangs: Losers and Outsiders" for Carey McWilliams at The Nation, the commissioned project documents Thompson's year-long association with the northern California motorcycle gang in photographs and writing.i 
Thompson emphasises the working-class nature of the gang in order to capture the Angels' menacing reputation and to mobilise the cultural value of that reputation by marketing it to the mainstream. He fully inhabits his role as a cultural omnivore able to turn fraught debates of representation into self-serving capital. By transforming cultural capital into symbolic capital in legitimised, highly circulated books and articles, Thompson and other New Journalists provide evidence that omnivoracity is, as Beverly Skeggs suggests, not only a "privilege restricted to the middle-classes" (Class \& Gender 125), but a method for the middle classes to "re-fashion and retool themselves" (Class \& Gender 144). Although he is perceived as a low-level practitioner of non-fiction and a creative transgressor of the class hierarchy, Thompson's narrative production and public performance as a New Journalist establishes a work persona that uses class identity to "re-tool" his status, and while his cultural omnivoracity may fashion a sense of control as a professional, it also reveals him to be "an asset-acquiring self, obsessed with increasing the volume of [his] cultural capital" (Skeggs Self 75).

The politics of representation and reputation are a central focus in the critical treatment of Thompson's early work. Best encapsulated by the International Journal of Motorcycle Studies' commemoration of the 40 th anniversary of Hell's Angels in 2005, the issue includes essays that overwhelmingly claim that Thompson lacked the authority to represent the bike gang and to influence cultural opinion. Ultimately concerned with an accurate representation of motorcycle culture and with the laws that stemmed from field reports about the motorcycle clubs, the IJMS critics find Thompson an ill-equipped sensationalist more interested in promoting his writing than providing a truthful impression of the club. For instance, Gary L. Kieffner's "Myth, Reality, and Revenge in Hunter S. Thompson's Hell's Angels" concerns itself not only with Thompson's skewed, outsider representations of the Angels, but also with his clear bias against them. Similarly, Barbara Joans' "GLIB WITH GUTS AND GORE: I Come to Bury HT, Not Praise Him: The Legend of Hunter Thompson," details the masculine command Thompson enacts in his depiction of the motorcycle club, which results in the development of cultural currency and celebrity despite his inadequate methods and perspectives. Both Kieffner and Jones suggest that Thompson's relationship to the Hell's Angels was troubled but productive, and that this tenuous connection "made" him as a writing professional and public persona.

Thompson is emblematic of the powerful command of class performance that New Journalists needed to enact to strengthen their own worker-writer personas. By staging social transgressions, Thompson is able to secure productive countercultural access through associations with the Hell's Angels. As a working-class community, the Hell's Angels provide Thompson the content that asserts his position as a "pro." The Angels also provide Thompson cultural material that secures his culturally omnivorous position. In order to turn these elements into creative New Journalism, Thompson strategically stresses three things: the gang's working-class history and frontier connections, his outsider status and non-membership to the gang, and the capriciousness of celebrity.

As a cultural omnivore, Thompson is able to connect the working-class identity of the Angels with a frontier mythos of mobile communities (e.g. hobos, gypsies). This pairing provides Thompson with a grand historical trajectory that corroborates the authority of his chosen profession, and the command of his cultural position. Since mobility is significant both to the Hell's Angels and to Thompson's ability to capture the story, his description of the Angels' "gypsy style of life" (Angels 150) suggests the cultural value of a mobile, outlaw community. Thompson stresses the group mythos more than the individual members of the gang in order to connect disenfranchised working-class men to a collective reassertion of turn-of-the-century masculinity rooted in railroads and the frontier.i In doing so, Thompson controls a familiar cultural narrative, providing validation and legitimacy to his choice of subject matter. For Thompson, this pairing ultimately demonstrates that despite the Hell's Angels low social standing, they possess a highly mobile mystique that he can put in service of his own career. 
To make this mystique appeal to his readers, Thompson connects the Angels to the visible iconography of the Westward promise of expansion, and to populist-era settlements in California. He explains: "It is easy enough to trace the Hell's Angel's mystique-and even their name and their emblems - back to World War II and Hollywood. But their genes and real history go back a lot further" (153). Thompson provides a historical evolution of working-class identity throughout the twentieth century, but one that stresses a nostalgic fascination with familiar and marketable emblems and names, rather than the material reality of nineteenth century frontier-era settlements in California. Thompson connects the Angels to the "rebirth" of California-strategically drawing on the iconic and popularised image of the Dust Bowl and its dispossessed populations-in order to stress the almost-mythical (re)settlement of nomadic labourers. Connecting the working-class past to the conditions of labour reform heroes and railriding troubadours like Woody Guthrie, who, in "1937 [...] expressed the frustrated sentiments of more than a million Okies, Arkies and hillbillies who made a long trek to the Golden State" (153), Thompson links the Angels to an idealized working-class sentimentality in order to assert his command over certain cultural and political aspects of the historical American landscape.

By approaching the Angels as "a kind of half-breed anachronism, a human hangover from the era of the Wild West" but "in other ways [...] as new as television," (Angels 66-7) Thompson establishes the gang as a group of exploited American workers displaced by history. This allows Thompson to use his working persona to appeal to his audience, but also redistribute the cultural currency and productivity of historically outsider and underdog positions. These roots allow Thompson to connect the Angels to a mobile group of working men in the West called the Linkhorns, whose interactions with mainstream society compromised their masculine character and become symbolic of the decline of the West. As a group made notable in the novels of Nelson Algren, Thompson defines Linkhorns as men who made "[d]rifting [...] a habit [...]. They kept driving west, chasing jobs, rumors, homestead grabs or the luck of some front-running kin" (Angels 154). Importantly, Linkhorns were buying into the American Dream by the middle of the twentieth century: "participating in the money economy; they owned decent car, and even houses" (Angels 154-5). But Thompson points out that other Linkhorns expressed discomfort with middle-class ideologies of upward mobility, and "broke down under the strain of respectability and answered the call of their genes" (Angels 154-5), to remain mobile and outside the status quo. This abbreviated twentieth-century genealogy marks a developing class divide spanning from the Depression to postwar prosperity, especially in California. In this context, Thompson selects a variety of working-class positions in history and acts as a bricoleur to establish a central thread of dispossession and rebellion against the emasculating and exploitative effects of middle-class or bourgeois life. These associations emphasise the mythos of the Angels as quintessential outsiders who attempt to assert, maintain, and stabilise their masculinity under capitalist domination, an appeal that struck close to home for Thompson and other New Journalists.

Despite staging a sense of the Angels' commonality with the working-class's historically outsider position, Thompson also shows the Angels in contrast to these nostalgic and romantic versions of Americana in order to offer the Angels as a perversion of Western idealism. In doing so, Thompson distinguishes himself from the working-class history he describes, and from the Angels, allowing him to assert a dominant position for his bourgeois individuality and his working persona. Although Thompson stresses his concern at "being slowly absorbed" by the Hell's Angels, his treatment of them as those working-class men, as we shall see, indicates a strict division between his investments and theirs (Angels 46). The success of this separation is indebted to Thompson's ability to construe the members of the Angels as working-class Others who are an unsophisticated group in need a mediating force like Thompson to achieve meaning. Thompson's boundary-crossing authorial position allows him to occupy a precarious, but productive position as both a part of and apart from the group. 
Thompson often explores the nuances of the Angels community by translating their wild actions and behaviours for his readers. Taking on the mediating role of a subculture-translator, Thompson establishes symbolic control over working-class culture in order to make visible his own authoritative status. For instance, he explains that the Angels' "swastika fetish is no more than an antisocial joke, a guaranteed gimmick to bug the squares, the taxpayers-all those they spitefully refer to as "citizens'" (245). Thompson stresses both the naivety of the viewpoint and the difference between the Angels and citizens as a method of distinction. This distinction continues when Thompson explains that by citizen, "[w] hat they really mean is the Middle Class, the Bourgeoisie, the Burghers-but the Angels don't know these terms and they're suspicious of anyone who tries to explain them" (245). Thompson's translation of "citizen" to the political discourse of "the Middle Class, the Bourgeoisie, the Burghers" announces his own intellectualism and his position as a privileged insider to his audience. By focusing on the Angels' limited vocabulary and hostility toward nuanced meaning, Thompson asserts his control as writer and master of language. These translations point to the Angels' lack of cultural capital and allow Thompson to place himself in an esteemed position as cultural arbiter. In this way, Thompson stresses his middle-class or bourgeois privilege to control not only the meaning of language, but also to legitimate working-class representations of the Angels.

Thompson's description of the Angels' initiation rites corroborates his privilege to translate the nuanced meaning of the gang to an audience. Offering depictions of the Angels' abjectness, Thompson offers hygiene as evidence of their Otherness:

Every Angel recruit comes to his initiation wearing a new pair of Levis and a matching jacket with the sleeves cut off and a spotless emblem on the back. The ceremony varies from one chapter to another but the main feature is always the defiling of the initiate's new uniform. A bucket of dung and urine will be collected during the meeting, then poured on the newcomer's head in a solemn baptismal. [...] These are his "originals," to be worn every day until they rot. (45)

Stressing their filth and depravity, Thompson uses the Angels' working-class bodies as ceremonial sites of a limited and ritualistic culture. Gesturing toward both sacrilege and the Angels as the unwashed masses, Thompson's Othering invokes his audience's fear of workingclass “contamination".iii Thompson's translation of the subculture, however, provides a mediating force that evades contamination despite his proximity to report it. For Thompson, contamination would result in a subordinated status that would inhibit his ability to recognise and distribute cultural capital, therefore, strictly distinguishing working-class bodies from his own becomes an important focus in his writing.

Thompson's fear of contamination also motivates his physical interactions with the Angels and his desire to emphasize his own individuality. This is particularly apparent in the second half of his text which focuses on the Angel's Independence Day ride to Bass Lake, just south of Yosemite National Park. Beginning his journey at the Bay Bridge, Thompson emphasizes that he drives to the lake in a car instead of riding his own motorcycle with the Angels. Expressing himself through this iconic symbol of middle-class American life, Thompson's observation of the gang from his isolated and self-contained car at the toll plaza is indicative of the physical separation required to maintain a cultural and class distinction from the Angels:

[W] hen I got to the toll plaza at the Oakland end of the bridge I asked the gatekeeper if any Hell's Angels had passed through before me. 'The dirty sonsabitches are right over there,' he said with a wave of his hand. I didn't know what he was talking about until some two hundred yards past the gate, when I suddenly passed a large cluster of people and motorcycles grouped around a gray pickup truck with a swastika painted on the side. They seemed to materialize out 
of the fog, and the sight was having a bad effect on traffic. [...] This stretch is hazardous on a clear afternoon, but in the fog of a holiday morning and with a Dread Spectacle suddenly looming beside the road the scramble was worse than usual. (111)

Aligning himself with the perspective of other drivers and the gatekeeper, Thompson becomes a middle-class "citizen" with a wary critical view of the Angels and their "Dread Spectacle." Thompson connects his working persona to a concerned and affected driving public who have been alerted and warned of the Angels' ride by radio bulletins, further stressing the Angel's menacing impact on the social and cultural geography of California. This scene, in turn, establishes Thompson as an important mediating force between the "looming" danger of the Angels and the orderly plaza and technological advancement of the bridge.

Thompson's vehicular position en route to Bass Lake similarly reiterates his separation from the "human zoo on wheels" (Angels 113). The car provides not only a degree of security, but additional mobility for Thompson because he can more easily take alternative routes to avoid the roadblocks put up by law enforcement to control the Angels' access to small towns. Thompson flaunts his all-terrain and omnivorous access as a car-going member of the middleclass: "According to the map, the last twenty miles appeared to be a gravel goat track [...] I swung left at Merced and floored it for a long roller-coaster-run throughout the foothills. Only two of the outlaws, both strays, made the mistake of taking the same route" (121). Thompson's leisurely "roller-coaster-run" on the "goat track" becomes a dangerous route for the "stray" motorcyclists, who are dehumanized in the face of Thompson's middle-class privilege. Moments like these emphasise Thompson's ongoing negotiation of a work persona that allows him to be close enough to capitalise on cultural events, but also distant enough so as not to lose the privilege of a cultural omnivore's accumulative potential.

Thompson's arrival at Bass Lake is integral to the success of the Angel's weekend event. As the driver of the car, Thompson's middle-class privilege becomes the Angels' lifeline against the police-dictated recreation area designated for them. This rural campsite has no supplies and, most importantly, no beer. As a car-going non-Angel, Thompson stresses his mediating capability and civic duty, able to code-switch between the Angel's camp, and the fearful but curious townspeople. Outside of the gaze of the law by disaffiliation, Thompson is permitted to head into town twice for beer runs. Thompson is secured and celebrated by his choice to drive to Bass Lake and is, simultaneously, able to assert and perform his separate status. Thompson's car reinforces the superiority of middle-class Americana, serving as both a symbolic "peace offering" purchasing his entry into the camp, and a secure sleeping place and ground-level observation deck for ensuing late-night rough-and-tumble behaviour.

Thompson's reports of parties like those at Bass Lake become part of the Angels' reputation in popular culture. Thompson is comfortable with the developing celebrity status of the Angels when it is credited to his New Journalistic work, but when other magazines and newspapers begin to take interest in the Angels-and more importantly, when the Angels themselves begin to see the potential of being paid for their appearances-Thompson is quick to discredit the gang. Speaking of this shift, Thompson describes the Angels at first as "something original," only to become a "mystique [... ] stretched so thin that it finally became transparent" (254). No longer an original story, Thompson has to put a new spin on the working-class roughness he had been reporting. Thompson self-servingly begins to discuss how the Angels' celebrity-in part created by Thompson himself-has made the Angels mediahungry and attention-starved individuals who now had confirmation that "they were rare, fascinating creatures" (Angels 57). As the Angels "become a factor to be reckoned with in the social, intellectual and political life of Northern California," their independent visibility and popularity at "half-bohemian parties" and within the media triggers Thompson's need to shift focus to maintain his own credibility (Angels 226). Thompson claims, "the Angels were far more impressed with the quantity of such coverage than the quality. Its total effect on them was 
considerable [...]. They were bona-fide celebrities, with no worlds left to conquer. Their only gripe was that they weren't getting rich" (Angels 42). For Thompson, like most cultural omnivores, celebrity is a by-product of bourgeois individuality, and is as such sanctioned only for those who have accumulated multiple avenues of cultural access and acclaim. Pitching the media-hungry acts of the Angels and their "giant masquerade" for attention, Thompson begins to depict the Angels as a spectacle, as dark outlines in the fog of the Bay Bridge, never fully detailed or truly valuable without his keen perspective (114).

A conversation at Bass Lake exemplifies the tensions over representation, when Oakland chapter founder, Sonny Barger, inquires about Thompson's work. Suddenly held accountable for his previous article about the Angels in The Nation, Thompson claims: "I had written the piece with the idea that I would never again have any contact with the motorcycle outlaws, whom I'd referred to as 'losers,' 'ignorant thugs' and 'mean hoodlums'” (Angels 139). Growing selfconscious in his precarious status as cultural arbiter, Thompson calls attention to the dread and volatility of having to "explain[ ...himself] while surrounded by a remote Sierra campsite by two hundred boozing outlaws (Angels 139). Forced to account for his past representations of the Angels and his current book project on them, Thompson's interaction with Barger focuses on the gang's sensationalist treatment by the press. Barger tells Thompson, "Well, we don't ask for nothin but the truth. Like I said, there's not much good you can write about us, but I don't see where that gives people the right to just make up stuff...all this bullshit, hell, ain't the truth bad enough for em?" (Angels 139). This exchange indicates not only the Angels' growing dissatisfaction with journalists like Thompson, but also the inherent danger for Thompson to be held accountable for his representations. Rather than serve as a reminder of his ethical obligations as a journalist, Barger's mild-mannered conversation is depicted as a moment for Thompson to consider his safety.

Thompson uses this conversation with Barger to set up the scene of his infamous stomping by the Angels. ${ }^{\text {iv }}$ In a footnote, Thompson addresses his conversation with Barger, interjecting that the Angels later "decided that truth was not enough. There would have to be money too. This created tension, which blossomed into resentment and finally violence" (Angels 139). To prove this development, Thompson ends his book with a postscript that details how he was beaten within an inch of his life: "On Labor Day 1966, I pushed my luck a little too far and got badly stomped by four or five Angels who seemed to feel I was taking advantage of them. A minor disagreement suddenly became very serious" (Angels 272). Thompson acknowledges his advantageous position as one of "luck," best defined by his ability to access the gang's inner circle despite his outsider status.

With the violent "truth" of the Hell's Angels imprinted upon his body, Thompson is able to offer himself as evidence in conjunction with the report. This stomping not only authenticates his insider-outsider work persona, but also garners interest and sympathy for the man who lived to tell the tale.v Thompson establishes himself not only as rogue journalist and professional writer, but also as celebrity in the literary marketplace and a cultural figure of notoriety and acclaim. When Thompson tells the tale of his stomping, he draws on the New Journalist's - and the cultural omnivore's-ability to transgress class-based space and power relations, advancing the self even against brute bodily force:

It had been a bad trip [...] fast and wild in some moments, slow and dirty in others, but on balance it looked like a bummer. On my way back to San Francisco, I tried to compose a fitting epitaph. I wanted something original, but there was no escaping the echo of Mistah Kurtz' final words from the heart of darkness: 'The horror! The horror! [...] Exterminate all the brutes!' (Angels 273)

Thompson calls attention to his position as cultural arbiter, invoking not only a Marlow-like ability to avoid "going native," but also the acclaim of narrating a tale of survival. ${ }^{\text {vi }}$ Despite his desire for "something original" to say, Thompson's cultural expertise invites alternative forms of 
representation in the Conradian allusion, and offers it as an emblematic, complex cultural "echo" that secures the position of cultural omnivore. In this final moment, Thompson uses both highbrow literature and brute violence to productively and profitably resource the underclass and to assert his bourgeois individuality in New Journalistic work.

\section{LOATHING THE PROFESSION}

Thompson's working performances of intellectual grit and survival in Hell's Angels also inform his best-selling novel, Fear and Loathing in Las Vegas (1971), which caricatures Thompson and his profession of journalistic cultural critiquevii Narrator Raoul Duke's version of a professional working persona is one that expresses a conscious awareness of the romance of the American landscape and its public appeal to the cultural marketplace of literary fiction. Depicting their version of professional journalism as a creative opportunity rather than a deadend job, Thompson and Duke celebrate the ability to ramble like a hobo and yet maintain gainful employment as a freelance journalist covering "the story." "But," as Duke asks, "what was the story? Nobody had bothered to say. So we would have to drum it up on our own. Free Enterprise. The American Dream. Horatio Alger gone mad on drugs in Las Vegas" (Fear 12). For Duke, covering the story is less important than participating in it; the story is an objective thing compared to the subjective experience of being a working American writer on the road. Duke is thus a paragon of the entrepreneurial work Thompson performs and professionalises, and Duke's journey and free-enterprising genre-blending offers an ethos for New Journalism that specifically defends Thompson's controversial work in Hell's Angels as a professional and profitable opportunity to tell a story.

As Tom Wolfe has noted, American literature has a tendency to invoke working-class associations in "terrific" biographical notes:

The author, you would be assured, was previously employed as a hod carrier (Steinbeck), a truck dispatcher (Cain), a bellboy (Wright), a Western Union boy (Saroyan), a dishwasher in a Greek restaurant in New York (Faulkner), a truck driver, logger, berry picker, spindle cleaner, crop duster, pilot [...]. There was no end to it [...]. Some novelists had whole strings of these credentials [...]. That way you knew you were getting the real goods [...]. ("Birth" 4-5)

In a cultural climate where working-class credentials make art "the real goods," it is no surprise that figures like Hunter S. Thompson work to maintain associations with working-class identities. In challenging the profession of journalism by crossing literary class boundaries, Thompson's professional personas are omnivorous and aim to exist at all levels at once. Yet, to cross class boundaries, Thompson's work must use practices that garner working-class sympathies and turn them into the "real goods" for the literary marketplace. These practices suggest that the subversive creative vision of New Journalism is rooted in the mobilisation of class, which allows figures like Thompson to enact a working persona that professionally markets the class positions of Others as an advantage for the construction of his own access and creative output.

By actively commodifying the working class-whether the Hell's Angels, low-level journalists, or hobo figures-Thompson's work relies on the reproduction of a social hierarchy to secure his own professional status and working persona. Thompson does not use representations of the working class to create strategic alliances that represent the material conditions for working class exploitation, dispossessed populations, or labour disputes. Instead, he uses these representations to perpetuate the cultural material of self-made, frontier-laden, autobiographical narratives that have been central to American literature and its marketplace

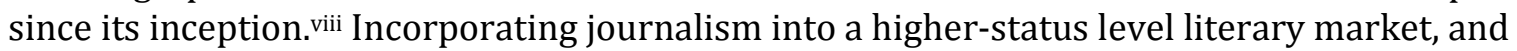
distinguishing himself against the working class, Hunter S. Thompson's work suggests a predilection for American literature to capitalise on underclass positions through culturally 
omnivorous practices. This professional status allows for the construction of strategic personas that engage in creative and intellectual work, but requires an association with those that physically labour to do it.

\section{END NOTES}

i The Nation is an American magazine known for its liberal-minded politics and critique. During his time as editor, McWilliams is credited with bringing the countercultural politics of the mid-twentieth century to a mainstream audience.

ii For a more comprehensive discussion of the frontier, see Richard Slotkin's influential Gunfighter Nation, which suggests that the frontier myths and myths of masculinity are concomitant in American cultural development.

iii Beverly Skeggs's Class, Self, Culture offers a provocative discussion of how workingclass bodies become part of a symbolic economy. She argues specifically "[d]irt and waste, sexuality and contagion, danger and disorder, degeneracy and pathology, became the moral evaluations by which the working-class were coded and became known and are still reproduced today" (4).

iv William McKeen's Outlaw Journalist: The Life and Times of Hunter S. Thompson provides a comprehensive series of events regarding Thompson's violent attack by the Hell's Angels. In his chapter “Among the Angels," McKeen stresses how Thompson's postscript describing the Bay Area stomping on Labour Day in 1966 becomes an immediate marketing technique for both Thompson's reputation and professional writing. McKeen highlights how interviewers and book reviewers clamored over the stomping, generating excitement that made Hell's Angels a best seller in 1967. This turned Thompson into a well-known name featured on news shows, game shows, and in large-circulation periodicals.

v In 1967, a Canadian Broadcasting Corporation (CBC) talk show set Thompson up to be confronted by Hell's Angel, Skip Workman, who participated in the stomping. Workman rides his motorcycle into the studio and confronts Thompson in front of an audience. Thompson is visibly fearful as the Workman retells what really happened when Thompson got stomped, indicating he was "mouthing off" and inserting himself unnecessarily into a situation of domestic violence. Workman points out: "he's sitting here and making a million dollars and he made it off of us" (CBC Archive). In terms of spectacle, this scene promotes a multitude of readings, both of Thompson as victim and of the Angels as brutes, although it is important to acknowledge that both parties are socially recognisable, treated as celebrities, and, at least in Thompson's case, continuing to profit from working-class representations.

vi In many ways, Thompson exemplifies the kind of strategic victimization Sally Robinson maps in Marked Men. Robinson argues that "Middle American" white men in the midcentury must respond to a social lack of control due to the multiple liberationist projects which side-line their identity. White masculinity, in turn, learns to mark itself as victim in order to reassert and realign patriarchal practices that reward male domination. Interestingly, the Hell's Angels can be seen as participating in this practice, too, in the above claim of Thompson's exploitation. 
vii The November 11, 1971 Rolling Stone cover for the publication of part one depicts narrator Duke on a red, white, and blue motorcycle wearing a gas mask. Ralph Steadman's depiction gestures toward Thompson's reputation with the Hell's Angels and Hollywood's fascination with male countercultural rebellion in films like The Wild One (1953) and Easy Rider (1969). Steadman's second cover and the story's conclusion were released on November 25, 1971. This image includes a more grotesque caricature of Duke injecting drugs in painful agony, and a Samoan Lawyer consuming a woman in the throes of passion and hunger. The dualities of the cover show the ongoing split in readership to date, some seeing Thompson as the documentarian of a crumbling American dream on the road, and others emphasising the drugriddled freedoms of the sixties. Overall, the novel argues that both attempts to explain the midcentury are lost by the fast-changes in politics and economy by the start of the seventies.

viii The Autobiography of Benjamin Franklin (1791) is one such prototypical example. Franklin relies on working-class figures to stress the integrity of his character and his ability to avoid doing physical labour.

\section{WORKS CITED}

Bourdieu, Pierre. Distinction: A Social Critique on the Judgment of Taste (1984). Trans. Richard Nice. Cambridge, MA: Harvard UP, 1996. Print.

CBC Archives. "Hunter S. Thompson Meets A Hell's Angel, 1967." YouTube. 7 July 2010. Web. 9 July 2015.

Easy Rider. 1969. Dir. Dennis Hopper. Perf. Dennis Hopper, Peter Fonda, Jack Nicholson. Columbia Pictures, 1999, DVD.

Franklin, Benjamin. The Autobiography of Benjamin Franklin. 1889. Classic American Autobiographies, ed. William Andrews. New York: Signet Classics, 2003. 70-228. Print.

Joans, Barbara. "GLIB WITH GUTS AND GORE: I Come to Bury HT, Not to Praise Him: The Legend of Hunter Thompson" International Journal of Motorcycle Studies 1:2 (July 2005). Web. 31 August 2015.

Kieffner, Gary L. "Myth, Reality, and Revenge in Hunter S. Thompson's Hell's Angels." International Journal of Motorcycle Studies 1:2 (July 2005). Web. 31 August 2015.

Newhouse, Thomas. The Beat Generation and the Popular Novel in the United States 1945-1970. Jefferson, NC: McFarland \& Company, 2000. Print

McKeen, William. Outlaw Journalist: The Life and Times of Hunter S. Thompson. New York: W.W. Norton \& Company, 2008. Print.

Peterson, Richard A. and Roger M. Kern. "Changing Highbrow Taste: From Snob to Omnivore." American Sociological Review 61.5 (Oct. 1996): 900-7. Web. 9 July 2014.

Robinson, Sally. Marked Men: White Masculinity in Crisis. New York: Columbia UP, 2000. Print.

Skeggs, Beverly. Class, Self, Culture. New York: Routledge, 2004. Print.

---. Formations of Class \& Gender: Becoming Respectable. London: Sage, 1997. Print.

Slotkin, Richard. Gunfighter Nation: The Myth of the Frontier in Twentieth-Century America. Norman, OK: U of Oklahoma P, 1998. Print.

Thompson, Hunter S. as Raoul Duke. "Fear and Loathing In Las Vegas: A Savage Journey Into the Heart of the American Dream." Rolling Stone 95 (November 11, 1971): 36-48. Print.

---. "Conclusion: Fear and Loathing In Las Vegas: A Savage Journey Into the Heart of the American Dream." Rolling Stone 96 (November 25, 1971): 38-50. Print.

Thompson, Hunter S. Fear and Loathing in Las Vegas (1971). New York: Vintage, 1998. Print. ---."Fear and Loathing at the Super Bowl” (1974). The Great Shark Hunt: Strange Tales from a Strange Time. New York: Summit Books, 1979. 46-96. Print. 
---. Hell's Angels. 1966. New York: Ballantine, 1994. Print.

---. "The Motorcycle Gangs: Losers And Outsiders." The Nation 200.20 (1965): 522-26. The Nation Archive. Web. 11 June 2015.

The Wild One. 1953. Dir. László Benedek. Perf. Marlon Brando, Mary Murphy. Mill Creek Entertainment, 2015, DVD.

Wolfe, Tom. "The Birth of 'the New Journalism'; Eyewitness report by Tom Wolfe." New York Magazine. 14 February 1972. Web. 14 July 2014.

---. "Why They Aren't Writing the Great American Novel Anymore." Esquire (December 1972): 152-272. Print.

Jennifer Hagen Forsberg is a PhD candidate at the University of Nevada Reno where she specializes in American literature and American Studies. Her dissertation "Rags, Riches and Rye: Hobohemian Narratives in Twentieth Century American Literature" examines the strategic use of class identification in popular culture, especially in iterations of the hobo narrative. 